アップデートセミナー 1

\title{
癌抑制型microRNA解析から見えてくる 上顎癌分子ネットワークの解明
}

\section{I. はじめに}

近年, タンパクコード遺伝子 (messenger RNA: mRNA）の発現調節に関わる遺伝子として, タンパク をコードしない機能性RNA（non-coding RNA: ncRNA） の一つであるmicroRNA（miRNA）が注目されている。 miRNAは真核生物のゲノム中にコードされている遺伝 子で，最終的に19〜24塩基長の低分子RNAとして機能 している。 miRNAは，塩基配列依存的にmRNAを標的 として, mRNAの分解やタンパク翻訳を阻害すること で遺伝子の発現を負に制御している（図 1 )。癌におい ては, miRNAの発現異常が様々な癌で報告されており, 癌の発生・増殖・転移において様々な miRNAが関与し ている事は明らかである。近年, 癌細胞や癌組織で発現 変化を認めたmiRNAを軸として，癌部で発現抑制され ている癌抑制型miRNA, 癌部で発現が充進している癌
野 畑二次 郎

千葉大学耳鼻咽喉科
遺伝子型miRNAの探索ならびに機能解析が盛んに行わ れている。また，これら miRNAの機能解析から，19〜24 塩基長のRNAが実際に癌抑制遺伝子，癌遺伝子として機 能している事が実証されている。miRNAの特徴として, 一つのmiRNAが複数のタンパクコード遺伝子を制御し ていることであり，これと同時に一つのタンパクコード 遺伝子は複数のmiRNAによって制御を受けていること から, 細胞内ではタンパクコード遺伝子とmiRNAを含 むncRNAとの非常に複雑な分子ネットワークが存在し ている事が容易に想像される（図 2 )。最近では，癌抑 制型miRNA ・癌遺伝子型miRNAを基点として, 癌細胞 におけるmiRNA分子ネットワーク（miRNA-タンパク コード遺伝子）の解明を試みる研究が盛んである。

癌研究において, 解析対象となるmiRNAの抽出には, ゲノムベースの発現解析が有効な手段となる。PCRベー ス・アレイベース・次世代シーケンサーなど様々なプラッ

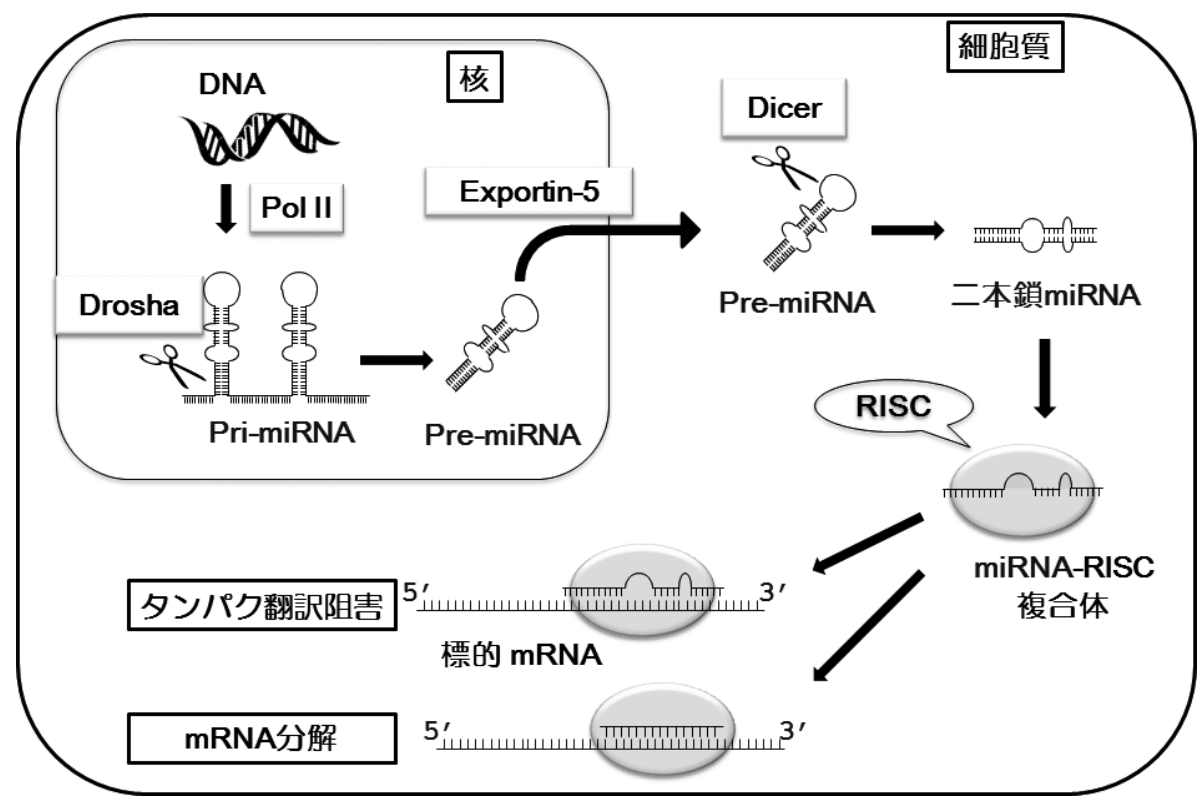

図 1 miRNAの合成経路 

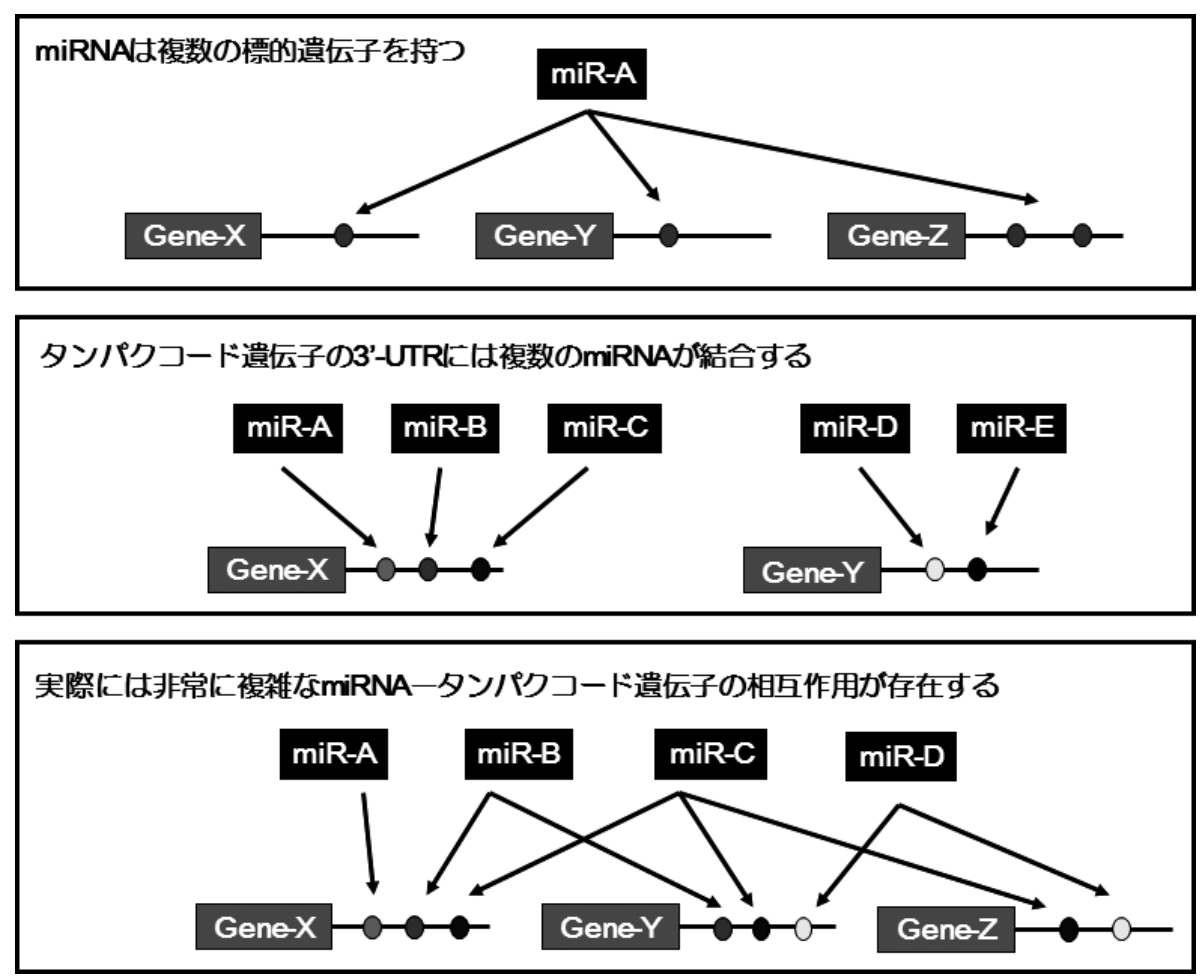

図2 miRNAとタンパクコード遺伝子の複雑な相互作用

\section{癌部で有意に発現低下していたmiRNA $(n=5)$}

\begin{tabular}{cccc}
\hline No. & miRNA & Fold change & P-Value \\
\hline 1 & miR-874 & 0.011 & 0.0463 \\
2 & miR-133a & 0.017 & 0.0033 \\
3 & miR-375 & 0.035 & 0.0161 \\
4 & miR-204 & 0.045 & 0.0055 \\
5 & miR-1 & 0.054 & 0.0240 \\
6 & miR-139-5p & 0.132 & 0.0044 \\
7 & miR-145 & 0.167 & 0.0367 \\
8 & miR-143 & 0.177 & 0.0190 \\
9 & miR-486-3p & 0.183 & 0.0407 \\
10 & miR-146a & 0.253 & 0.0041 \\
\hline
\end{tabular}

miR-874expression by qRT-PCR $(\mathrm{n}=20)$

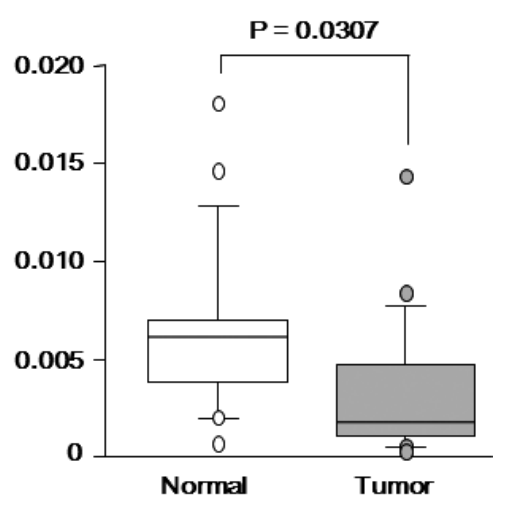

TaqMan Human microRNA Low Density Array V2

図 3 上顎洞偏平上皮癌のmiRNA発現プロファイリング。上顎癌において $m i R-874$ は有意に発現低下している。

トフォームにより，比較的低コストで短時間かつ正確に 癌で発現変動するmiRNAを探索することが可能になっ てきた。 miRNAの解析手段の充実と共に癌における miRNA研究は飛躍的に増加している。

しかしながら, 上顎癌（扁平上皮癌）における miRNAに関する解析はこれまで報告されていなかった。 そこで今回我々は上顎癌の癌抑制型miRNAの同定とそ の分子ネットワークの解明を試みたので報告する。

\section{II. 方 法}

上顎洞扁平上皮癌の臨床検体 5 例を用いてmiRNAの 発現プロファイルを作成した。発現プロファイルに基づ き有意に発現低下を認めたmiRNAについて細胞株 IMC-3を用いて増殖能・浸潤能に関する機能解析を施行 した。癌抑制型miRNAが制御する分子ネットワークを バイオインフォマティクスの手法を用いて探索した。 


\section{XT丁生存能アッセイ (增殖能 72hr)}

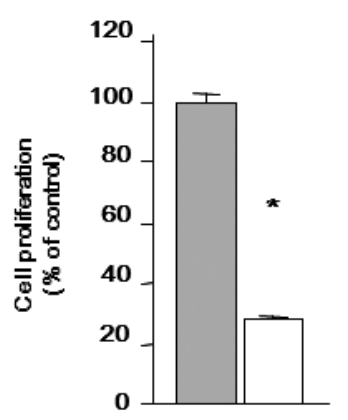

\section{細胞数カウント}

（増殖能 72hr）

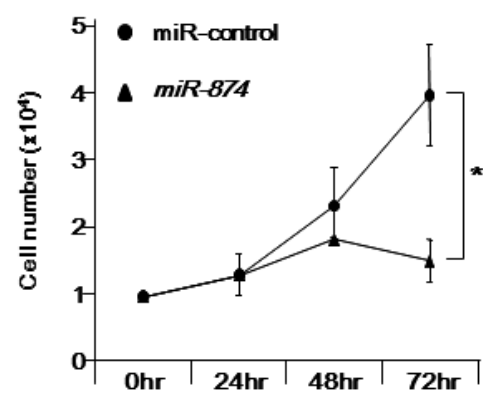

\section{インベージョンアッセイ}

（浸潤能 72hr）
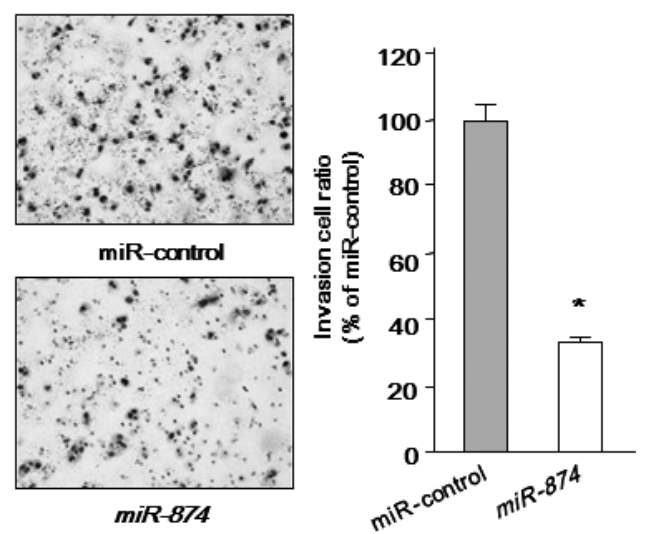

細胞株：IMC-3（上顎癌由来） *:P<0.05

図4 miR-874の機能解析 $(m i R-874$ を導入; $10 \mathrm{nM})$

III. 結 果

我々が作成した上顎癌miRNA発現プロファイルにお いて最も発現低下していたmiR-874に注目した。臨床検 体20例を用いた解析の結果，miR-874は癌部で有意に低 下していた（図 3)。さらに，上顎癌細胞株IMC-3に miR-874を導入した結果, 癌細胞の増殖や浸潤を抑え, 癌抑制機能を有することが示唆された（図 4 )。miR-874 が制御する標的遺伝子（分子ネットワーク）を探索する 際, 生物学的データベースを用いて絞り込みを行った。 配列予想プログラム（TargetScanHuman）と分子パス ウエイ解析プログラム (GeneCodis) を組み合わせた結果, miR-874はMAPKシグナリングに含まれる遺伝子群と配 列結合性を有意に持ち, 特にNTRK2, STNM1, CDC25B の発現を制御している可能性が示唆された（図 5 )。こ れらは上顎癌の新たな治療標的候補と考えられた。

\section{IV. 考察}

以上の結果から, 機能性RNA分子が関与する上顎癌の 新規癌分子ネットワークの一端が解明され, さらに上顎 癌の新規治療標的候補が見出された。我々は今後これら に関する検討をさらに深化させていきたいと考えている。

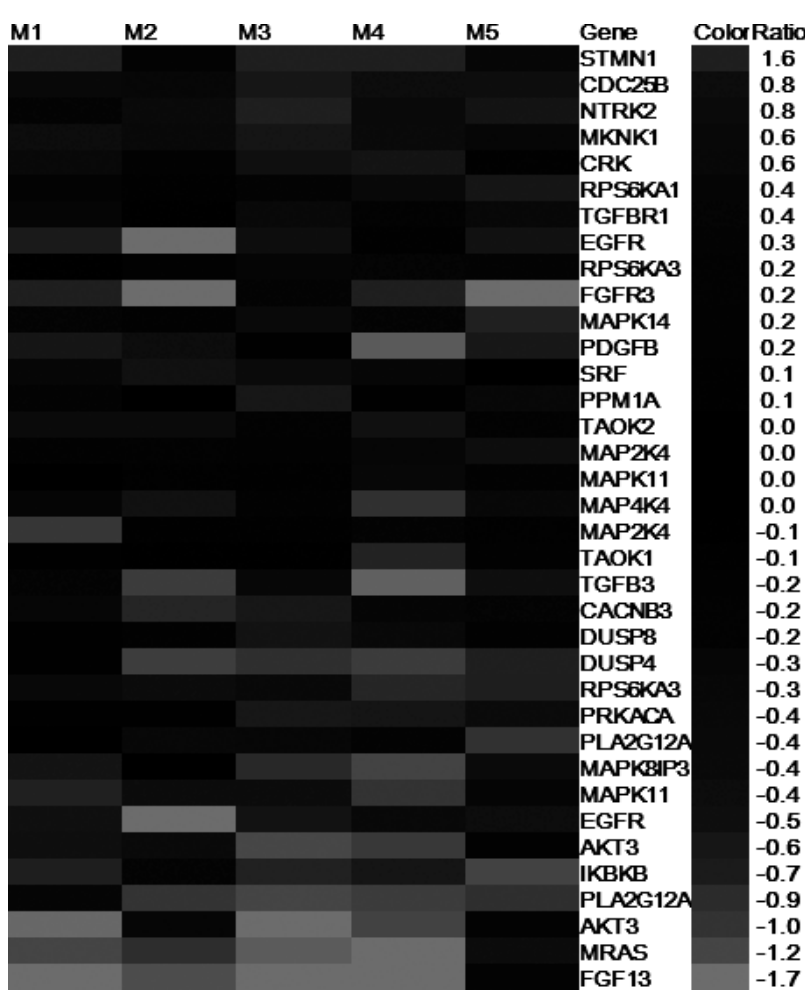

図 5 MAPKシグナルに関与している遺伝子の発現（上顎 癌 5例マイクロアレイ解析GSE36951) 